\title{
The Role of Higher Institutions in Creating Awareness on Challenges of MUIP in Communicating its Waqf Possession
}

\author{
Noraini Mohamad ${ }^{1 *}$ \\ Zahanum Zulkifli' \\ ${ }^{1}$ School of Dental Sciences, Health Campus, Universiti Sains Malaysia, \\ 16150 Kubang Kerian, Kelantan, Malaysia \\ *Corresponding Author, Email: mnoraini@usm.my
}

\begin{abstract}
This paper analyzes the fenomena regarding issues of waqf and its impact on the ummah development. Waqf has significant impact on the ummah development in term of social, economic, political and legal process. The good governance of waqf institutions of waqf assets and properties, MUIP in particular has enhanced the economic, education and worship of the ummah within the MUIP jurisdiction. Waqf reported as an important aspect of religious ummah's activity, that is increasing the awareness of social care.
\end{abstract}

Keywords: Waqf, Awareness, Ummah development

\section{A. INTRODUCTION}

Majlis Ugama Islam dan Adat Resam Melayu Pahang or MUIP was established as a corporation in 1992 under the Enakmen Pentadbiran Undang-Undang Islam Negeri Pahang 1991. The Ruler of the State - the Sultan of Pahang is the Head of Islamic Religion and within the clauses of the Enactment, the Sultan could establish a Majlis that became its role to advise and assist him on state religious matters and Malay culture. Thus, MUIP was established as a sole trustee of Waqf under section 70 of the Enactment. Pahang is among the six (6) states after Federal Territory, Penang, Selangor, Melaka and Negeri Sembilan that was successful in setting up the Waqf Division with enough staff to assist in establishing the Waqf Process and Procedure, Documentation, Waqf data base etc. Also, it has become known that the waqf activity in Pahang has begun since 1470 (Abidin, 2006). However, in term of disclosing waqf assets and properties information, the Majlis has finally able to produce its first Annual Report for financial years ending 2011 and 2012. Information displayed in the Annual Report revealed much awaiting information required by all type of stakeholders.

Meanwhile, Malaysia has ample number of Higher Education of Learning Institutions, beginning from Vocational Academies, Community Colleges in most Districts in all states of Malaysia, Polytechnics, University Colleges, Private and Public Universities. These are the institutions for achieving intellectual security in communities, as these are the places where refine minds of scholars, studies and research platform qualify them in all aspects of life.

The establishment of higher institutions in Malaysia was pioneered by University of Malaya (1962), University of Science Malaysia (1969) and followed by the National University of Malaysia (1970). The later university is the only university, which adopts Bahasa Melayu as its medium of 
instruction and has proven its success. The current twenty (20) public universities in Malaysia have been categorized into groups of Research universities (5), Comprehensive universities (4) and Focus Universities (11). In addition, USM has received an international accreditation as APEX Institute of Learning that will be the center to steer education excellence in the region. Within these higher institutions, they established several research center of excellence in multi-disciplines with the objectives of recovering new ideas, developing new theories, methods of resolving a set of research objectives, which give benefit to the ummah and communities, they served. This paper seeks to disclose the challenges faced by MUIP in disclosing information on it waqf assets and properties. In addition, the paper intends to examine on how the Higher Education of Learning Institutions in Malaysia could assist MUIP in overcoming their difficulties.

\section{B. METHODS}

This paper uses the data related from Majlis Ugama Islam dan Adat Resam Melayu Pahang (MUIP). This paper reviews the activities of waqf in Pahang. It discusses a clear description of waqf challenges, event, and legal aspects of waqf in Pahang.

\section{RESULT AND DISCUSSION}

\section{Challenges faced by MUIP in disclosing Waqf information}

\section{a. Waqf Assets Register}

The Council has established a Waqf Assets Register that records inventory of general and specific waqf assets in the state of Pahang. However, by year 1991, the Council no longer accepted any waqf assets for special purposes. Thus, the current available Waqf assets for specific purposes are in the process of transferring under section 70 (Waqf and Nazar) and section 73 of the Enactment (Sekatan sekatan ke atas pengwujudan Amanah Khairat). The Waqf Assets Register now contains registration of general waqf in the form of land and properties in the State of Pahang and Cash waqf. The current list of Waqf properties under the custodian of Pejabat Saham Wakaf Pahang (PSWP) is eleven (11) units of shop houses along Jalan Mahkota Kuantan, a unit of building at Bukit Ubi Kuantan Rd. and a unit of house in Pekan, Pahang. The later information was well documented and a complete list of information is delivered to the respective District and Land Office. Even without the existence of any computerize database, the Council did the updating of waqf data systematically. On the other hand, all District waqf records are maintained by the Council. Islamic District offices do not keep any waqf records on their premises because all waqf transactions must be done at PWSP in Kuantan. In addition, though the record of waqif's name, date, location of waqf property or asset, the purpose, quantity, size and other related information on waqf were recorded in the Waqf Register, the Council does not maintain an individual file of the waqif. Thus, future references made difficult.

\section{b. Waqf Land}

Although MUIP has established its own Waqf Division to handle Waqf matters, the Council was still unable to disclose the complete record of the type of movable or immovable waqf assets and properties, the Ringgit value of its waqf properties in hand, information on the number of waqf properties and its value that have been developed, invested or been transferred to Kumpulan Wang Khairat Am (KWKA). Under the Sections 67 and 72 of the Enactment, the Council can direct any waqf assets and properties that are non waqf beneficial to the community, the value of these 
assets and properties are to be transferred to KWKA. The reason being, the Pejabat Saham Wakaf Pahang (PSWP) does not adopt the concept of waqf istibdal, where the unwanted or unused waqf assets and properties can be substituted with another fertile land or pricey commercial land or premises or exchange with value of cash. However, on leasehold waqf lands, the Council continues to pay its premium until the expiry date.

At this instance, the Council is in the process of reconciliation of all waqf land available in the State of Pahang against information recorded in the Register of Waqf Assets. The process of identifying the location, status and size of waqf land involved under developed and neglected land at $\mathrm{Kg}$. Lipat Kajang, Temerloh, Pahang, and those lands endowed before the year 1957. On the process of transferring and registration of ownership of the waqf land, MUIP does not face with any challenges. All the process was done in accordance to the process and procedure of land transferring and registering. As of November 27, 2013 the total number of waqf land in the ten (10) districts of State of Pahang are registered at 144 lots with a total area of 74.6 hectares (see table 1).

Table 1: Waqf Land - Statistic by Pahang District

\begin{tabular}{|l|l|l|l|l|l|}
\hline No & District & No. of Lot & $\begin{array}{c}\text { Size } \\
\text { (Hectares) }\end{array}$ & $\begin{array}{c}\text { Developed Waqf } \\
\text { Land (Hectares) }\end{array}$ & $\begin{array}{c}\text { Under Developed } \\
\text { Waqf Land } \\
\text { (Hectares) }\end{array}$ \\
\hline 1 & Temerloh & 21 & 7.34 & 0 & 7.34 \\
\hline 2 & Kuantan & 33 & 11.61 & 1.74 & 9.87 \\
\hline 3 & Pekan & 36 & 11.12 & 0 & 11.12 \\
\hline 4 & Lipis & 11 & 9.23 & 0 & 9.23 \\
\hline 5 & Jerantut & 4 & 1.03 & 0 & 1.03 \\
\hline 6 & Rompin & 8 & 2.78 & 0 & 2.78 \\
\hline 7 & Raub & 7 & 7.65 & 0 & 7.65 \\
\hline 8 & Bentong & 9 & 14.8 & 0 & 14.8 \\
\hline 9 & Maran & 11 & 7.81 & 0 & 7.81 \\
\hline 10 & Bera & 4 & 1.23 & 0 & 1.23 \\
\hline & & & 74.6 & 1.74 & 72.86 \\
\hline & Total & 144 & (Source: MUIP) & \\
\hline
\end{tabular}

Alternately, JAWHAR reported that waqf land for the State of Pahang stand at 723.82 hectares, valued at RM18 million (see table 2). The record from JAWHAR stated that the waqf land in Pahang was classified under special waqf. Both information on Pahang district of waqf land and data from JAWHAR were retrieved on the same month of November 2013. Interesting, in 1991 the State of Pahang has stopped receiving waqf for special purposes. And all waqf classified under specific purposes has been transferred to KWKA under section 70 of the Enactment.

Table 2: Waqf Land in Malaysia

\begin{tabular}{|l|l|l|l|l|}
\hline \multirow{3}{*}{ States } & \multicolumn{1}{|c|}{$\begin{array}{c}\text { Waqf land } \\
\text { (Hectares) }\end{array}$} & \multicolumn{1}{|c|}{ Total (hectares) } & \multirow{2}{*}{ Value (RM) } & \\
\cline { 2 - 4 } & General & Special & & \\
\hline Johore & $1,422.80$ & $1,729.50$ & $3,152.30$ & $7,000500.00$ \\
\hline Kedah & 156.62 & $1,086.25$ & $1,244.88$ & $1,997.00$ \\
\hline Kelantan & 16.01 & 157.63 & 173.65 & $56,703,373.00$ \\
\hline
\end{tabular}




\begin{tabular}{|l|l|l|l|l|}
\hline Malacca & 11.65 & 21.60 & 33.25 & 66.50 \\
\hline Negeri Sembilan & 1.01 & 14.49 & 15.50 & 36.00 \\
\hline Pahang & 0.00 & 723.82 & 723.82 & $18,000,000.00$ \\
\hline Perak & 116.12 & 0.00 & 116.12 & 383.00 \\
\hline Perlis & 2.74 & 14.49 & 17.23 & $1,337,998.00$ \\
\hline Penang & 220.03 & 559.23 & 779.26 & $850,000,000.00$ \\
\hline Sabah & $2,091.38$ & 35.95 & $2,127.33$ & 112.00 \\
\hline Sarawak & 6.86 & 4.04 & 10.90 & $1,416,781.90$ \\
\hline Selangor & 235.63 & 31.82 & 267.45 & $200,000,000.00$ \\
\hline Terengganu & 34.54 & 126.64 & 161.18 & $7,023,869.00$ \\
\hline Federal Territory & 0.49 & 1.59 & 2.08 & 16.00 \\
\hline Total & $4,317.88$ & $4,507.07$ & $8,824.95$ & $1,141,485,132.40$ \\
\hline
\end{tabular}

(Source: Wakaf @ e-bayanat, JAWHAR, accessed on 27th November, 2013)

Data of Waqf Land in the State of Pahang reported by JAWHAR was ten times (10) higher than the actual number in the record of Waqf Land of Pahang (see Table 1). In addition, in the record of JAWHAR none of the waqf land in Pahang was developed for use. But, from Table 1, it shows that in the district of Kuantan 1.74 of 11.61 hectares has been developed (see Table 1 and 3).

Table 3: List of Developed Waqf Projects in Pahang

\begin{tabular}{|l|l|l|l|l|l|l|}
\hline No & Project & $\begin{array}{l}\text { Cost } \\
\text { (RM) }\end{array}$ & $\begin{array}{l}\text { Financed } \\
\text { by }\end{array}$ & Implementer & Category & $\begin{array}{l}\text { Year } \\
\text { Developed/ } \\
\text { Operation }\end{array}$ \\
\hline 1 & Kompleks Asnaf & 3.5 million & MUIP & MUIP & $\begin{array}{l}\text { Religious/ } \\
\text { Social }\end{array}$ & $2009 / 2010$ \\
\hline 2 & $\begin{array}{l}\text { Bazaar (27 units } \\
\text { in 5 Districts) }\end{array}$ & 1.58 million & $\begin{array}{l}\text { JAWHAR } \\
\text { RMK 10 }\end{array}$ & YWM & Business & 2010 \\
\hline & & & & & \\
\hline
\end{tabular}

(Source: MUIP)

On development of waqf land, MUIP has established a committee consists of the State Legal Advisor, Deputy State Mufti, State Financial Officer, Director of Economic Planning Unit, Director of Land and Minerals and MUIP representative. The committee's members meet every three (3) months to review, consider and approved waqf land application and other matters relating to waqf land. Thus, the development of the two (2) MUIP waqf projects had received the committee approval. Interestingly, on how the records have been mismatch remains unresolved. In term of reporting of waqf assets and properties, all MAINs are to submit their reports to JAWHAR for waqf assets and properties consolidation, in order to obtain a combined figure of waqf assets and properties available in Malaysia. Information on Waqf Land displayed in Table 1 and 2 questioned the correctness of the data collected and information in Table 3 revealed the miscommunication or non-communicated data between JAWHAR and the MUIP.

\section{c. Waqf land valuation}

The land was valued based on market value however the financial reporting is based on historical cost. The market value of waqf land was not for financial disclosure purposes. Even though the Waqf Assets Register was frequently updated with information as per Table 1, the actual value of those waqf land were not at present market value of the land. The Council estimated the value of the waqf land based on the market value of the neighboring properties in that district. The Council could not appoint a Licensed Surveyor to do so, due to cost constraint. The appointment of a 
Licensed Land Surveyor is necessary when the waqf landis to be developed or for verification purposes in preparing the Land Document or Grant.

\section{Annual reporting of waqf assets and properties}

The first Annual Report of 2011 was published in year 2012, while Annual Report of 2012 was published in year 2014. Prior to year 2012, all waqf information were written in MUIP bulletins, brochures or pamphlets that being published three (3) times a year. The information could be collected from MUIP and Islamic District Offices in Pahang or when MUIP held exhibitions elsewhere within or outside Pahang. However, on waqf reporting, it remained as an internal matter but could be viewed upon request. Data on waqf is shown in 2 parts;- the Statement of Income and Expenditure for KWKA and Waqf Trust Fund. Unfortunately, the disclosure of waqf land was not available in those reports. This is due to the waqf nature that Abidin (2012) mentioned that the definition of waqf adopted by the State of Pahang is from the Shafi'i sect:

"waqf is any property which waqif has no more rights on the property, of any other business transactions, inheritance, grants and wills, while maintaining the physical resources for charitable causes with the intention to draw closer to Allah SWT - which waqf property should be beneficial and enduring"

The Council concludes that, waqf land and properties are of no value to be classified as Assets in the financial reports due to the nature of the properties that could not be sold for profit. The disclosure of actual waqf value is when the waqf assets and properties are developed or commercialized. According to the Council, their role is to ensure the waqf assets and properties are used in accordance to requirement stated by the waqif. The Council is powerless to administer the assets and properties at its own will and discretion. Thus, the only ASSETs reported in the Annual Report are those belonging to the Council.

\section{The research center of excellence roles in accommodating the challenges faced by MUIP}

The establishment of Higher Education Research Centers such as Accountancy Research Institute (ARI), Institute Kajian Zakat and Waqf, UiTM, Center of Awaqf Financing Development, USIM, all specializes in conducting Waqf matters within their units. Their research were either fully funded by government sources, financed by individual MAINs, self financing by researchers or funded by Universities sources to encourage research activities, strengthen research centers position and concurrently raised university ratings. IKaZ, for instance has proposed the erecting of UiTM mosque at Puncak Alam to be based on cash waqf (salaries deduction of UiTM staff) and a joint venture with Bank Islam Malaysia Berhad under the Murabahah financing concept. On the other hand, the Accounting Research Institute received yearly research grant from the Ministry of Education to undertake research on Islamic Forensic Accounting research, while Majlis Agama Islam Negeri Sembilan funded research by the Center of Awaqf Financing Development, USIM.

\section{Legislation and policy}

At federal level, JAWAHAR is a center of reference for the accumulation of all waqf data from MAINs of various states in Malaysia. The non-compliance of MAINs towards the requirements of the Enactment stirred data discrepancies. Though, harmonization of state and federal laws almost seen impossible, but a directive from JAWAHAR and a stern punishment to MAINs non- 
compliance in providing waqf information for the benefit of the Ummah could reduce data disparities. The experts from the Faculty of Pengajian Islam, UM and UIAM could be summoned to be the facilitator in harmonization of the laws. It is notified that the manpower at MUIP consists of an officer (an accountant) and he is being supported by twelve (12) supporting staff of various grades.

On conversion of waqf land status from specific to general purposes, MUIP is in the process of transferring a number of waqf land lots that have mosques, surau and graves on it to MUIP's. At the moment these lots of land are being supervised by the state of Pahang. These land need to be registered under MUIP to comply with the requirement of section $416 \mathrm{C}$ of the National Land Code that granted rights to occupy, use, control or manage the land but has no right to own it as a landlord. An unregistered waqf land will not be recognized as waqf land under the section code of the National Land Code 1965 even though it is legitimate waqf land under the jurisdiction of Islamic law enshrined in section 70 of the Enactment. MUIP will become the trustee of the land and the land can be developed for social, religious or commercial use. Upon completion of registration, then only, the waqf land will be accounted and reported as Waqf Assets and Properties for that financial year.

The sections 67 and 72 of the Enactment provide that those unused or undeveloped waqf land or waqf land of no value or have not determined its usage, need to be transferred to Kumpulan Wang Khairat Am (KWKA). This process of transferring has lessened the number and value of waqf land but will increase the number and amount of assets owned by the Council. The concept of istibdal need to be revisited by MUIP so as the waqf assets - Land could be developed or used as per waqif intentions.

On the other issue is recognizing rental revenue on building constructed on waqf land. The confusion arose with the understanding that building erected on waqf land, if it is rented will automatically be rent of waqf in nature. However, the $77^{\text {th }}$ Muzakarah of the Fatwa Committee of the National Council of Islamic Religious Affairs Malaysia, held in 2007 had produced a decision that the completed building on waqf land is not automatically converted to a waqf property. The land needs to be registered as a new waqf property and must fulfill the requirements of waqf and State Enactments. Any Baitulmalland owned by MAINs and the construction of building on the land was financed by the Waqf Land Development Program Fund, this land can be registered as waqf property. However, the building erected will forever remain as non-waqf asset unless either JAWAHAR or MAINs reverse the building status.

\section{Waqf valuation, reporting and recording}

The argument of valuing waqf land at market value is accepted in Islam and is considered appropriate. The current cost or the market value is preferred because it represents the real time value of the assets and is considered fair to do so. Many Islamic scholars agreed that current cost method or market value reflects the current situation and relevant for future references.

On the other aspects, the council disclosed waqf assets and properties of higher value that give positive impact to the stakeholders. While those assets and properties of lower value and under developed were merely recorded and not reported. This practice led to difficulties in determining the location, status and value to be accounted for in the financial reporting. 


\section{CONCLUSIONS}

Waqf has significant impact on the ummah development in term of social, economic, political and legal process. The good governance of waqf institutions of waqf assets and properties, MUIP in particular has enhanced the economic, education and worship of the ummah within the MUIP jurisdiction. Opinion, assistance and joint venture projects with higher institutions center of research excellence, religious scholars will fill-up the information gaps and knowledge to draw the stakeholders closer to waqf.

The importance of waqf can be referred to several verses in the Qur'an and the Sunnah of the Prophet SAW. Many verses of Qur'an and the hadith refer to the duality impact of waqf for the benefit of ummah both now and hereafter.

Waqf reporting is important to demonstrate the accountability and transparency of mutawalli in managing and administering of waqf affairs. Increasing the awareness of waqf to the stakeholders need to be parallel with the increase in the waqf reporting. Stakeholders on the other hand may review the performance of the respective waqf with high level of trusts and as a result encourage other stakeholders to endow their assets and properties. 


\section{References}

Abidin, M. Z. Z. 2006. "Pengurusan Tanah Waqf Di Negeri Pahang: Satu Tinjauan." In Seminar Kebangsaan Pengurusan Harta.

2012. "Pengurusan Dan Pembangunan Tanah Wakaf Di Negeri Pahang." 